\title{
Unprotected Insurance: a Case from Jiwasraya
}

\author{
Taofik Hidajat \\ \{inidotcom@yahoo.com\}
}

Sekolah Tinggi Ilmu Ekonomi Bank BPD Jateng, Jl.Soekarno Hatta 88, Semarang, Indonesia

\begin{abstract}
This paper aims to highlight the un prudent governance of insurance companies and explores the causes of the bankruptcy of the Indonesian state-owned insurance company, Jiwasraya. It is a general discussion using the Indonesian regulatory regime, company financial reports, and investigative reports as the central reference point. This study's findings are un prudent corporate governance, unclear business models, and weak supervision are the causes of bankruptcy and default. The novelty of this research is that there are no studies that specifically highlight the Jiwasraya bankruptcy case that practices unethical practices, namely the Ponzi scheme, window dressing, and financial statement fraud.
\end{abstract}

Keywords: insurance, Ponzi, bankrupt, Jiwasraya

\section{Introduction}

The life insurance industry in Indonesia is experiencing shocks. Two insurance giants, Jiwasraya and Bumiputera, suffered heavy losses. How can a large insurance company collapse and fail to protect its customers? This paper takes the Jiwasraya case. Jiwasraya is a large insurance company that is experiencing financial problems and has failed to pay obligations to policyholders. The leading cause of Jiwasraya's bankruptcy is the mismanagement of investments. This company has a portfolio of stocks with a poor performance that causes negative spreads, liquidity pressures and defaults.

This case began in 2002. At that time, the company was already experiencing financial difficulties. Based on the records of The Audit Board of the Republic of Indonesia (BPK), Jiwasraya reported fictitious profits since 2006 by manipulating financial statements. Through window dressing, the company records apparent profits. In a loss condition, the company became a sponsor of the world soccer club in 2014, Manchester City. In 2015, the company released a product called the Jiwasraya Saving Plan (JS Saving Plan) with the cost of funds exceeding deposit and bond interest. However, the product funds are invested in stock investment instruments and mutual funds with poor performance. The purchase and sale of shares are carried out pro forma and is not based on valid and objective data. Jiwasraya placed IDR 5.7 trillion in $95 \%$ of the poor performers and IDR 14.9 trillion in $98 \%$ of poor-performing investment managers.

The company's wealth is smaller than the liability (insolvency) due to investment policy mistakes and liquidity pressure on saving plan products. As of February 2020, the value of assets is IDR 22 trillion, and equity is IDR 29 trillion with liabilities of IDR 51 trillion. Risk-based capital (RBC) minus 1307\%, far below the minimum regulatory standard of $120 \%$. Debt claims reached IDR 16.7 trillion. Ninety-seven per cent of the debt claims are dominated by JS Saving Plan products. 
JS Saving Plan is a hybrid insurance and investment product that is distributed through bancassurance such as unit links with a tenor of 1 to 5 years. In the unit link, investment risk is borne by the policyholder while the saving plan is borne by the company. The JS Saving Plan guarantees a high yield of between 9\% and $13 \%$ per year for 2013-2018. During this time, this product contributed greatly to the company's growth. Its performance also beat other large insurance companies. Although the number of policyholders of this product is only $0.24 \%$ of 7 million customers, the contribution of premiums reaches 35\% [1]. This product makes Jiwasraya in 2017 ranked second in the collection of premiums. Gross premiums jumped fantastic from Rp 2.31 trillion to $\operatorname{Rp} 21.80$ trillion.

Looking at the JS Saving Plan launch period, this product seems to be an anticipation of technological disruption and corporate losses. Disruption requires insurance companies to make creative and innovative efforts to be able to survive [2]. The inability to answer this challenge makes the company issued a product that is attractive to prospective policyholders, even though it has considerable risk. The company has also been losing money since 2004 but is practising window dressing to enhance its financial statements.

The promise to provide high returns makes the company invest in instruments that can provide tremendous returns such as stocks and equity funds. Shares are not liquid assets while these products mature every day. To manage the portfolio, the company works with 13 fund managers. However, the poor performance of the stock portfolio makes customer confidence go down by not extending (rollover) the maturing JS Saving Plan. It makes the company's obligations increase because the company has already run a Ponzi scheme.

This case is interesting to discuss because Jiwasraya is a large insurance company that has become a benchmark for other insurance companies. The ultimate shareholder of this company is The Ministry of StateOwned Enterprises, as the representative of the Indonesian government that is responsible if the company loses. Policyholders are also not only residents of Indonesia, but also residents and foreign companies, especially from South Korea. There are more than four hundred South Koreans who buy this product. Besides, the insurance industry is very regulated.

Insurance fraud is a global economic problem that threatens companies and the insurance industry [3]. According to Hayirsever (2020)[4], insurance fraud not only affects insurance companies, policyholders, but also the insurance industry as a whole. The cost of fraud damage affects the profitability of the company and hurts society. As exemplified by the failure of AIG, the collapse of this company not only harmed the American economy but also played an essential role in the 2008 global financial crisis [5]. The bankruptcy of financial institutions that have branches in 130 countries has an impact on global financial markets. Banks around the world are forced to reduce the value of their portfolios and reassess them.

The purpose of this paper is to explore the causes of the bankruptcy of the Indonesian state-owned insurance company, Jiwasraya. The collapse of large insurance companies is a valuable lesson so that business processes and company operations can continue to maintain public confidence. The unfolding of this scandal could cause the public and customers to be afraid of investing in insurance. The case of this company can be a lesson for insurance companies and authorities not to make the same mistakes.

\section{Methodology}

This paper uses a qualitative-descriptive research method. This method does not construct hypotheses and analyze relationships between variables but rather describes a phenomenon, in this case, Jiwasraya. The data used in this paper comes from the Indonesian regulatory regime, company financial reports, and investigative reports. From this source, an analysis was conducted to find out the cause of Jiwasraya's loss.

\section{Results and Discussion}

\subsection{The Collapse of the Giant}

The most significant contribution of Jiwasraya's bankruptcy is not doing good governance. If the company carries out regulatory provisions (POJK No.73/POJK.05/2016) regarding the management of insurance companies, this problem probably will not occur.

This incident is reminiscent of Black Swan Theory. Black Swan is a shocking event, has a significant impact and should be expected (prevented) before it happens [6]. The bankruptcy of Jiwasraya surprised the public because the majority shareholder and supervisor of the company were the Indonesian government. This case has a significant impact because of the massive amount of losses. However, this incident can be prevented. Apart from not complying with regulations, there are operational activities that also trigger bankruptcy. The following are some of the practices that cause Jiwasraya's bankruptcy that should have been prevented before the case.

Supervision of commissioners and authorities. 
In POJK regulation No.73/POJK.05/2016, there is the role of an independent commissioner as a party that is not affiliated with management and shareholders. According to the regulation, an independent commissioner is a member of the board of commissioners who is not affiliated with shareholders or other relationships that can affect his ability to act independently. Independent commissioners should also supervise the management and bring the interests of policyholders. Independent commissioners are even required to report to Financial Services Authority $(\mathrm{OJK})$ if the board of commissioners rejects the evaluation of an independent commissioner on a policy that is detrimental to policyholders. Commissioners can use other resources to help supervise one of them using public accountants. However, this oversight function does not work. Some activities that are detrimental to the company do not get a warning from the commissioner.

The bankruptcy of Jiwasraya also raises questions about the role of regulators and regulatory forces in overseeing the insurance industry. The Financial Services Authority is the third tier guard after shareholders and commissioners. This authority is in charge of giving signs to insurance companies. Various company decisions, such as the purchase of shares is a management policy that should receive supervision from shareholders and commissioners. Although the authorities have made many efforts by releasing various regulations and conducting strict supervision, the Jiwasraya case made the Financial Services Authority fail to carry out this task. This stigma of failure does not need to occur if the Financial Services Authority not only receives company reports but also actively analyzes in detail the conditions and business processes of the company. In the case of Jiwasraya, the JS Saving Plan was stopped not because of an order from the Financial Services Authority but a company initiative.

Some of the causes of weaknesses in oversight and independence of the Financial Services Authority are prioritizing harmony and avoiding conflict, using supervised industrial funds, ignoring good corporate governance, choosing political leaders and less competent human resources [7]. In some cases, authority is not strict with government-owned companies like Jiwasraya. Authority avoids conflicts but causes problems later. Until now, the authorities still receive contributions from industry to finance operational activities, purchase assets and pay employees. This condition can make the authority not independent, especially for companies that pay substantial contributions. Consequently, good corporate governance is also challenging to implement. Moreover, the election of authority leaders uses a political process involving the President and the senate. Another weakness of authority is the lack of competent human resources. Many young employees and have no experience of making the supervised party more experienced than those who supervise.

\section{Negative spread dan window dressing.}

Realization of investment results in lower yields (negative spread) so that it appears defaulted due to liquidity disruptions. This condition occurs because most of the stock portfolio consists of shares and mutual funds with bad fundamentals.

Problems arise because stock prices with bad fundamentals continue to decline. This condition is dangerous because the investment return is not enough to meet the claims reserve. To cover these losses, the company practiced window dressing. Management manipulates the stock price by buying shares that are overpriced in the regular market, selling in the negotiated market below the purchase price and then buying back the shares. The practice of window dressing occurred in the 2017 financial statements. At that time, the company recorded profits even though according to the auditor's notes, there were losses. This action is fraud top management. Fraud top management is the deliberate action of management at any level to deceive, manipulate or cheat investors or other key stakeholders [8]. The practice of window dressing has been happening for a long time, but the authorities also still allow the JS Saving Plan to circulate in the community.

\section{Ponzi scheme.}

Poor portfolio performance and high guaranteed returns on investment premiums have forced companies to run Ponzi schemes. The Ponzi scheme is an investment model in which investor income comes from other investor funds that have recently joined or not come from investment returns [9]. This scheme has existed since 1920 and continues to this day. This pyramid scheme will end when no new investors join. Major scandals in the financial world who have used Ponzi among them is Bernard Madoff.

This scheme occurs because Jiwasraya must guarantee a definite return to customers. Profits from stocks cannot provide positive returns. Moreover, the stock portfolio consists of stocks with poor performance. Through the Ponzi scheme, old customers will get money (claims due) that comes from new customers, not from investment returns. According to Eisenberg \& Quesenberry (2014)[10], there are six causes for people to invest in Ponzi. The six factors are people who believe in the promise of operators that provide high returns, the emergence of irrational optimism after seeing others get investment returns, deluded by one's personality and reputation, persuaded by a promise of return that exceeds market returns, convincing appearance of Ponzi operators, and want to be a part from the exclusivity of the group which is a cover. Customers are interested in buying the JS Saving Plan because this product gives high yields and is owned by the government.

\section{Financial statement fraud.}

There are two premiums in the JS Saving Plan, namely the protection premium and investment premium. Protection premiums guarantee the risk of death, are helpful and will be given to heirs if the customer gets a 
disaster. Investment premium provides a return on investment to customers in the future. In the protection premium, there is a mortality risk, and in the investment premium, there is investment risk. For mortality risks, life insurance companies will pay the insurance money to the heirs or beneficiaries if the insured dies using the mortality table as a guide. For investment risk, the company will provide a return to policyholders. These yields are generally lower than the fixed income or deposit interest rate effects.

These premium records should be separate because they are different products. The purpose of this separation is to facilitate the supervision and review system of insurance management. However, the JS Saving Plan insurance premium recording system in the financial statements does not separate the premium components for protection and investment premiums. Because there is no separation, the risk of the product cannot be assessed.

Large premium income is known after a case of default. The big problem is that the significant premium income comes from investment premiums that promise higher returns than deposit interest rates. The exact yield ranges from $9 \%$ to $13 \%$ per year, higher than the growth of the composite stock price index, bond yields and deposit interest. High fixed returns derived from stock portfolios violate the investment logic. Theoretically, there are no investment instruments that in the long run, can beat the market performance consistently. Stock is an instrument that although it can provide a significant profit, but cannot provide a guarantee of profit because it is a type of instrument that is not risk-free. High risk, high return.

The second recording error is recording premiums as income. Premiums are debt, not company income. Premiums are money owned by customers, not the company.

\subsection{Lesson Learnt}

Learning from the Jiwasraya case, there is a poor corporate governance and weak insurance sector regulation. The authorities also have not overseen this sector optimally. Some regulations related to investment, financial health, and the submission of financial statements have not been appropriately implemented. The Jiwasraya case should be a lesson to improve the industry and insurance companies. Here are some ways to avoid the case from happening again.

\section{Integrated surveillance.}

There are still gaps in regulations, data and information so that it is difficult for authorities to monitor irregularities. Integration of supervision will make it easier for authorities to detect fraud. So far, the integration of sophisticated systems is still in the banking sector. Tajudeen \& Abdur (2009) [3], who conducted a study in Nigeria, showed that the indecisive attitude of the insurance industry supervisory authority that began with unclear sanctions could lead to economic crime.

The Financial Services Authority must have an integrated system that oversees the insurance, banking and capital market sectors. The financial crisis in 1998 taught a lesson that the authorities were unable to detect fraud in the capital market. The nonbank financial industry invests more in the capital market because it is liquid. Unlike in the banking sector, there is no short term liquidity market in the insurance sector. Until December 2019, insurance investment reached IDR 580.31 trillion in the form of mutual funds $(32.09 \%)$, shares $(26.31 \%)$ and government securities (15.12\%). Besides, there must also be restrictions on investment portfolios to avoid fraud. For example, medium-term notes (MTN) are prone to be misused because this transaction does not go through a public offering process on a stock exchange.

\section{Establish a risk-based early warning system.}

In addition to increasing integrated supervision of investment portfolios, authorities need to develop an early warning system. This system will provide a warning if the investment performance of insurance companies falls. According to Schwarcz \& Schwarcz (2014)[5], systemic risk of insurance companies is not only because of its size but also because of the similarity and correlation of insurance products, investment strategies, risk exposures, risk management, and greater interconnection to the financial system. These similarities, correlations, and linkages continue to change, thus requiring an insurance regulatory structure that can proactively identify, assess, and manage new potential sources of systemic risk.

\section{Supervisor independence.}

Independence has four dimensions, namely, regulatory, supervisory, institutional, and budgetary. The financial crisis in East Asia, Russia, Turkey and Latin America provides a lesson that political interference in financial sector regulation will worsen the situation. Politicians are involved when passing regulations, but when regulations apply, politicians may not interfere with regulators [11]. In order to maintain that independence, the Financial Services Authority's operational budget sourced from financial institutions should be eliminated. Although levies do not interfere with the independence of regulators of financial services institutions such as in Korea and Japan, this policy can avoid conflicts of interest.

Implementation of good governance and effective risk management through three lines of defence (3LD). 
The 3LD model makes corporate resilience stronger against risk. The first layer of defence is in a business unit or function that carries out the company's operational activities. The second layer of defence is in the risk management and compliance functions. The third layer of defence is in the internal and external auditors.

For public companies in Indonesia that adopt a two-board system, there are company directors who have executive accountability and a board of commissioners that has oversight accountability. The Board of Directors has an internal audit unit, and the board of commissioners has an audit committee. The three layers of defence are under accountability and direct coordination of the directors of the company while the board of commissioners has indirect accountability for the third layer of defence.

The insurance industry also needs to implement an actuarial control cycle (ACC) to review whether controls have been carried out properly, evaluate 'pricing evaluations' and ensure financial health, including reserve claims obligations.

\section{Implement a policy guarantee institution.}

Unlike the banking industry and capital market which guarantees customer funds through the Indonesia Deposit Insurance Corporation (IDIC) and the Securities Investor Protection Fund (SIPF), there is no guarantor institution for the insurance industry. The establishment of the Policy Insurance Agency was mandated in Law Number 40/2014 concerning Insurance.

The establishment of an insurance policy guarantee institution is needed to guarantee risk if the insurance company goes bankrupt and prevents moral hazard. The existence of a policy guarantee institution has a positive impact on the growth of the insurance industry because public confidence will increase. Through this institution, insurance protection premiums are re-guaranteed to reinsurance companies. Like IDIC and SIPF, this agency is not authorized to improve company liquidity but closes and returns customer funds if the company experiences a financial crisis. Life insurance products that are guaranteed are traditional insurance, health, accident and unit link protection. Unit link investments, as well as investments with guaranteed returns exceeding the guaranteed rate, are the customer's responsibility. The reinsurance company will become a particular policy guarantee institution for the protection premium component. Although investment premiums cannot be included in reinsurance guarantees because reinsurance cannot guarantee investment risk, this can prevent Ponzi schemes and facilitate the reinsurance process.

\section{Improve reporting system regulations to improve insurance company governance.}

The recording of the protection premium and investment premium in the financial statements must be separated. Separation of the recording of protection premiums with investment premiums in accordance with International Financial Reporting Standard (IFRS) recommendations. IFRS 17 reporting standards require insurance companies to use the current discount rate to assess liabilities. IFRS 17, which replaces IFRS 4, is a financial accounting standard to regulate internationally agreed accounting treatment for insurance contracts.

The application of IFRS 17 in the insurance industry will be a significant challenge in the next few years [12]. The report revealed that IFRS 17 insurance accounting standards would increase compliance risk and implementation costs. In practice, the implementation of IFRS has a positive effect as in the Korean capital market [13].

Although it causes the assets of insurance companies to fall, IFRS 17 will make financial statements more transparent and make it easier for stakeholders to understand financial statements [14]. Mohammad, K., \& Han (2020) [15] who surveyed companies listing on the Saudi Arabian stock market concluded that the majority of respondents supported the conversion to IFRS because it produced higher quality and transparent financial reports. Financial report transparency is essential because information asymmetry makes it difficult for consumers to evaluate the quality of insurance company policies and allows both parties to act opportunistically [16].

\section{Improve human resource competence.}

Insurance is a business that prioritizes trust. To maintain that trust, human resources in each line must be competent. Directors, commissioners and employees must have competence, especially risk management. Investment managers must have investment and portfolio management expertise. Actuarial competence also plays a role in overseeing insurance products to prevent default. Supervisory capacity should be better than that supervised, so the authorities need to add experienced employees in finance. According to Isaac, Charles, \& Dei (2016) [17], adequate training for insurance marketers is one way to prevent insurance fraud.

\section{Increasing public insurance literacy and inclusion.}

A national financial literacy survey from the Financial Services Authority in 2019 showed that the financial literacy index reached 38.03 per cent and the financial inclusion index 76.19 per cent. Although in general, the level of literacy and inclusion rose from the previous period, insurance penetration is still low. Insurance penetration in Indonesia is still in the range of 2-3 per cent [18]. Of the 267 million inhabitants, the total premium is only 4.7 million and is concentrated in big cities. Three main factors that cause Indonesian people to be reluctant about insurance products are related to procedures for obtaining, high prices, and not understanding the product and its benefits [18]. 
It takes many efforts to make people aware of the importance of insurance because there is a relationship between insurance market penetration and economic growth [20], [21]. Insurance should be a subject matter from primary education to tertiary education.

With a vast population, the insurance industry in Indonesia has many opportunities to develop. There are many variations of products that can be created. One of the interesting opportunities today is insurance technology platform because technology is a medium that can increase penetration. Through this platform, companies can sell insurance products through the web or application.

Another opportunity is to work with peer-to-peer (P2P) lending services. In Indonesia, there is a lot of illegal $\mathrm{P} 2 \mathrm{P}$ billing that is unethical [22]. Lack of knowledge about the legality of online loans makes many people fall victim to illegal $\mathrm{P} 2 \mathrm{P}$ lending. Insurance cooperation with $\mathrm{P} 2 \mathrm{P}$ lending aims to mitigate loan defaults and avoid unethical billing. P2P has a fund lending product with an instalment payment mechanism. The risk of lenders is not able to repay the loan. Insurance can provide loan insurance cover by giving a replacement of the remaining loan.

\section{Conclusions}

The main problem of Jiwasraya occurs because it ignores the principle of prudence in investment, window dressing, mispricing, pressure on the liquidity of saving plan products and weaknesses of supervision. The Jiwasraya case provides a lesson that good insurance corporate governance is essential, but not strong enough to prevent fraud.

So that the case does not recur, it is necessary to reform the financial services industry from upstream to downstream, including the insurance sector. These reforms include an integrated surveillance system, implementing a policy guarantor institution, implementing an early warning system, recording financial reports following international standards and improving human resource competencies.

Insurance literacy needs to increase insurance penetration. Knowledge of insurance since primary education is one long-term solution. To increase revenue, insurance companies need to innovate products through the use of technology.

\section{References}

[1] K. Mohamad, “The Future of Unit Linked and Saving Plan Products after Jiwasraya's Accident,” Infobank, Jakarta, pp. 84-85, Mar. 2019.

[2] M. Naylor, "The Impact of Disruptive Technology," in Insurance Transformed, Springer, 2017, pp. 47-92.

[3] O. Y. Tajudeen and R. B. Abdur, "Control of insurance fraud in Nigeria: an exploratory study (case study)," $J$. Financ. Crime, vol. 16, no. 4, pp. 418-435, Jan. 2009, doi: 10.1108/13590790910993744.

[4] B. F. Hayirsever, "Insurance Fraud: The Case in Turkey," in Contemporary Issues in Audit Management and Forensic Accounting, vol. 102, S. Grima, E. Boztepe, and P. J. Baldacchino, Eds. Emerald Publishing Limited, 2020, pp. 77-97.

[5] D. Schwarcz and S. L. Schwarcz, "Regulating systemic risk in insurance," Univ. Chicago Law Rev., pp. 1569-1640, 2014.

[6] N. N. Taleb, The black swan: The impact of the highly improbable, vol. 2. Random house, 2007.

[7] K. Mohamad, "OJK's report card: banking supervision to be done by Bank Indonesia?," Infobank, Jakarta, pp. 8687, Feb. 2020.

[8] S. Zahra.A, "Understanding the causes and effects of top management fraud," Hum. Resour. Manag. Int. Dig., vol. 15, no. 7, Jan. 2007, doi: 10.1108/hrmid.2007.04415gad.001.

[9] T. Hidajat, "Predator and prey: Ponzi and pyramid investors," in Facing Global Digital Revolution: Proceedings of the 1st International Conference on Economics, Management, and Accounting (BES 2019), July 10, 2019, Semarang, Indonesia, 2020, p. 147.

[10] H. D. T. Eisenberg and N. W. Quesenberry, "Ponzi Schemes In Bankruptcy," vol. 30, no. 3, 2014.

[11] M. Quintyn and M. W. Taylor, "Should Financial Sector Regulators Be Independent?, dans «IMF Economic issue»." 2004.

[12] Centre for the Study of Financial Innovation, "Insurance Banana Skins 2019. The CSFI survey of the risks facing insurers," 2019.

[13] K. G. Key and J. Y. Kim, "IFRS and accounting quality: Additional evidence from Korea," J. Int. Accounting, Audit. Tax., p. 100306, 2020, doi: https://doi.org/10.1016/j.intaccaudtax.2020.100306.

[14] S. Yanik and E. Bas, "EVALUATION OF IFRS 17 INSURANCE CONTRACTS STANDARDS FOR INSURANCE COMPANIES,” Press. Procedia, vol. 6, no. 1, pp. 48-50, 2017.

[15] N. Mohammad, J. E. K., and D. Han, "Implementing IFRS in Saudi Arabia: evidence from publicly traded companies,” Int. J. Account. \&amp; Inf. Manag., vol. 28, no. 2, pp. 243-273, Jan. 2020, doi: 10.1108/IJAIM-042019-0049.

[16] R. Swedloff, “The New Regulatory Imperative for Insurance,” Bost. Coll. Law Rev., vol. 61, no. 5, 2020. 
[17] A.-F. Isaac, A. Charles, and O.-H. E. Dei, "Causes, effects and deterrence of insurance fraud: evidence from Ghana," J. Financ. Crime, vol. 23, no. 4, pp. 678-699, Jan. 2016, doi: 10.1108/JFC-11-2015-0062.

[18] Daily Social Research, "Insurance Technology Survey 2019," Jakarta, 2019.

[19] Daily Social Research, "Startup Report 2019: Scaling Through Technology Democratization,” Jakarta, 2020.

[20] R. P. Pradhan, B. M. Arvin, N. R. Norman, M. Nair, and J. H. Hall, "Insurance penetration and economic growth nexus: Cross-country evidence from ASEAN,” Res. Int. Bus. Financ., vol. 36, pp. 447-458, 2016.

[21] A. A. Latif, "Insurance market development and economic growth: Exploring causality in 8 selected African countries," Int. J. Soc. Econ., vol. 43, no. 3, pp. 321-339, Jan. 2016, doi: 10.1108/IJSE-09-2014-0182.

[22] T. Hidajat, "Unethical practices peer-to-peer lending in Indonesia," J. Financ. Crime, vol. 27, no. 1, Dec. 2019, doi: 10.1108/JFC-02-2019-0028. 